


\title{
THE EFFECT OF STORAGE ON PHYSICAL, CHEMICAL AND MICROBIOLOGICAL CHARACTERISTICS OF FISH WASTE ACIDIFIED USING FERMENTED VEGETABLES WASTE EXTRACT
}

\author{
B. Sulistiyanto ${ }^{1}$ and K. Nugroho ${ }^{2}$ \\ ${ }^{1}$ Faculty of Animal Sciences, Diponegoro University, Semarang-Indonesia \\ ${ }^{2}$ Kalbe Farma, Surabaya-Indonesia, Gedung Enseval Jl.Berbek Industri VII No.6-10 Waru, \\ Sidoarjo, East Java - Indonesia \\ Corresponding E-mail:bsoel07@gmail.com
}

Received February 9, 2011; Accepted May 23, 2011

\begin{abstract}
Fish waste ("ikan rucah") is part of discarded fishing product, which is composed by non-food categorized fish (NFC-fish). Quality of NFC-fish meal that was made by dipping in extract of fermented vegetable's waste has been reported better than commercial fish meal, but the effect after storing remained in question. Experiment was conducted to study the effect of different time of storing on physic-organoleptical, chemical and microbiological characteristics of the acidified NFC-fish meal that was made by dipped in extract of fermented vegetable's waste (FVW-exctract). The NFC-Fish was soaked in the FVW-exctract by the ratio 1:1 (w/v) for 4 hours, and then it was dripped out and dried. The dried fish was ground passed through 20 mesh, kept into plastic bags and stored at the room temperature (23-25 ${ }^{\circ} \mathrm{C}$ and $\left.70-80 \% \mathrm{RH}\right)$ for $0,1,2$ and 4 months. Physic-organoleptical, chemical and biologycal characteristics were parameters observed. Experiment was conducted by completely randomized design (CRD). Data were analysed by the GLM of SAS. Actual number of moisture, crude protein, extract ether, and proteolytic bacteria of fish meal were significantly influenced by time of storing $(\mathrm{P}<0.05)$. Dipping NFC-fish in the FVW-exctract effectively maintain the physical characteristics, $\mathrm{pH}$, moisture, crude protein, extract ether and the number of proteolytic bacteria of fish meal up to 2 months of storage. Dipping NFC-fish in the FVW-exctract provide better characteristics on physical, chemical and microbiologycal than the commercial fish meal at the same condition of storage.
\end{abstract}

Keyword : acidified, extract vegetable, storage, fish meal, characteristics

\section{INTRODUCTION}

Fish waste ("ikan rucah") is part of local fishing product waste that was composed of nonfood categorized of fish. That is almost 5-10\% of fishing product and it contains high protein $(>36 \%)$. Fish waste has been recognized as source of protein for animal feeding. The conventional method of fish meal production in farmer's scale is the technology constrain and its quality. To obtain high yield and quality of fish meal, it was necessary method skills and experience in cooking, pressing and drying. These technologies were not easy and high cost in operation (Barlow and Windsor, 1984; Solar et al., 2005; Folador, 2006; Amiza et al., 2011). Organic wastes of traditional vegetable markets were potential local resources. Our previous study noted that fermentation of vegetable waste provided product which was rich in organic acid and total number of lactic acid bacteria were $3.5 \times 10^{9} \mathrm{cfu} / \mathrm{mL}$. Acidified fish meal has advantages in terms of application technology and quality in compared to conventional fish meal.

Soaking is an alternative acidifying technique in preservation. Soaking fish meal in the Sauerkraut-extract (FVW-extract) was reported increasing microbiologycal and physical performances than that of commercial fish meal (Sulistiyanto and Nugroho, 2009), and prevented the growth of bacteria in the smoked products of silver catfish (Pangasius sp) (Amin and Leksono, 2001). It was reported that solution extract of fermented vegetables could be applied as a sources of organic acids which was rich in lactic acid bacteria, and those play role in maintaining the physic-organoleptical and microbial performance of the product of acidified fish meal. Lactic acid bacteria were known to have potential for preservation as well as suppressing the 
development of microbial pathogens such as NFC-fish (Utama and Mulyanto, 2009; Sumarsih et al., 2010). The process of soaking is expected to provide acid atmosphere so that impedes autocatalytic process in the fish meat and prevent activity of decomposing microorganisms, so it will produce of acidified fish meal with a good performance.

Sulistiyanto et al. (2011) noted that the number and viability of LABs of FVW-extract remain stable after pelleting process, and feeding that pellet significantly increased the total number of LABs and suppressed the number of pathogens in the gut of chickens. Storaging generally caused characteristics' exchange and decreased the total number of bacteria that may lead to decreasing the quality of product (Malaka and Laga, 2005; Prachyakij et al., 2006; Katikou et al., 2007). The previous study noted that dipping into FVWextract effectively reduced the content of total bacteria, fungi and proteolytic's bacteria in fish meal. The effect of the FVW-extract was presumably stable to maintain the quality of the fishmeal product during storing. Therefore, the experiment aimed to study the influence of different storage time on physic-organoleptical, chemical and microbiological characteristics of the acidified fish meal that was made through dipped the fish in the fermented vegetable's waste extract.

\section{MATERIALS AND METHODS}

Extract of fermented vegetable's waste (FVW-extract) that was made by Chinese green mustard and cabbage wastes, was mixed with $2 \%$ of salt $(\mathrm{w} / \mathrm{w})$ and $6.7 \%$ of molasses $(\mathrm{w} / \mathrm{w})$, and was incubated for 6 days. Extraction was done mechanically, it was pressed by $10 \mathrm{~kg} / \mathrm{cm} 2$ for 5 minutes, and the FVW-extract was then used to acidify "Rucah" fish. The Fish $( \pm 60 \mathrm{~kg})$ was chopped to 3-4 cm, then was soaked into FVWextract by ratio $1: 1 \quad(\mathrm{w} / \mathrm{v})$ for 4 hours, subsequently it was drained and dried. The dried acidified fish was ground passed through 20-40 mesh, kept into plastic bags $( \pm 2.5 \mathrm{~kg})$ and stored at the room temperature $\left(23-25{ }^{\circ} \mathrm{C}\right.$ and $70-80 \%$ $\mathrm{RH}$ ) for $0,1,2$ and 4 months. The commercial fish meal was stored within 4 months storing since it was taken from poultry shop. To that physicorganoleptical characteristics, $\mathrm{pH}$, moisture content, crude protein, crude fat, total fungi and total proteolytic bacteria were observed. Physicorganoleptical characteristics were conducted by panels (9 panels) to observe odor, color and texture. $\mathrm{pH}$ was measured after diluting fish meal with water 1:1 (w/v), mixed well, stand up for 15 minutes, and then measured the $\mathrm{pH}$. The moisture content, crude protein and crude fat were analysed by the method of AOAC (1997). Total fungi and total proteolytic bacteria were determined by the method of Fardiaz(1993). Statistical analysis was conducted by the GLM-SAS (SAS-Institute, 1982).

\section{RESULTS AND DISCUSSION}

Result of experiment noted that weight loss from a fresh form to be a fish meal product (moisture content $\pm 10 \%$ ) of acidified with FVWextract method was lower than that of conventional method, that was 48 vs $62 \%$ vs $62 \%$ $(\mathrm{P}<0.05)$. Table 1 showed the resume a result of the experiment. The result showed that during 2 months of storage, physical characteristics i.e.: odor, color and texture did not change significantly $(\mathrm{P}>0.05)$. It was significant after 4 months of storing, in particular of texture which was a bit dense $(\mathrm{P}<0.05)$. In general, the physical appearance was better than commercial fish meal that was stored for 4 months under the same conditions. The $\mathrm{pH}$ values of fish meal was in acidic conditions that was $3.8 \pm 0.2-5.5 \pm 0.1$. While the commercial fish meal $\mathrm{pH}$ tended from neutral to alkaline. The moisture content increased with the time of storage. There were $7.7 \pm 2.8 ; 8.7 \pm 2.3 ; 8.9 \pm 3.2$ and $13.3 \pm 2.3 \%(0,1,2$ and 4 months of storage). The significant increment was shown in time of 4 months storage $(\mathrm{P}<0.05)$. Crude protein content did not significantly change during 2 months of storage (59.54, 61.39 and $60.64 \%)$, and it significantly decreased at 4 months of storage $(58.14 \%)$, although it was higher than those in the commercial fish meal $(45.86 \%)$ that stored for same period $(\mathrm{P}<0.05)$. The content of ether extract tended to decrease with the increasing of storage time $(8.82,8.12$ and $8.74 \%)$. It was significantly decreased in the time of storage of 4 months $(7.84 \%)$. The ether extract of acidified fish meal was lower than those of commercial fish meal $(11.45 \%)$ that was stored for the same condition $(\mathrm{P}<0.05)$. Fungi was not found in fish meal made with the technique of dipping in the solution of fermented vegetable extract, while the fungi was found in the commercial fish meal, there was amounted to $2.2 \times 10^{2} \mathrm{cfu} / \mathrm{g}$. The total 
Table 1. Physical, Chemical and Microbiological Characteristics of Fish Meal Made by Dipping into Extract Pickled Vegetables

\begin{tabular}{|c|c|c|c|c|c|c|c|c|c|}
\hline $\begin{array}{l}\text { Storage } \\
\text { Time } \\
\text { (month) }\end{array}$ & Odor & Color & Texture & $\mathrm{pH}^{2)}$ & Moisture $^{3)}$ & $\begin{array}{c}\text { Crude } \\
\text { Protein } 3 \text { ) }\end{array}$ & $\begin{array}{l}\text { Extract } \\
\text { Ether }{ }^{3)}\end{array}$ & $\begin{array}{c}\text { Total } \\
\text { Fungi }\end{array}$ & $\begin{array}{c}\text { Total } \\
\text { Proteolitic } \\
\text { Bacteria }^{4)}\end{array}$ \\
\hline & & & & & \multicolumn{3}{|c|}{ 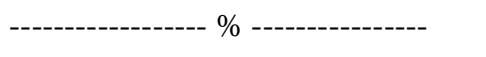 } & \multicolumn{2}{|c|}{-------- cfu/g -------- } \\
\hline 0 & $\begin{array}{l}\text { Fresh } \\
\text { sourish } \\
\text { smell, } \\
\text { typical fish } \\
\text { meal }\end{array}$ & $\begin{array}{l}\text { Light } \\
\text { brown }\end{array}$ & crumbly & $3.8 \pm 0.2^{\mathrm{c}}$ & $7.7 \pm 2.8^{\mathrm{c}}$ & $59.54 \pm 2.3^{\mathrm{a}}$ & $8.82 \pm 2.8^{\mathrm{b}}$ & ND & $4.8 \times 10^{5 b}$ \\
\hline 1 & $\begin{array}{l}\text { Fresh sourish } \\
\text { smell, typical } \\
\text { fish meal }\end{array}$ & $\begin{array}{l}\text { Light } \\
\text { brown }\end{array}$ & crumbly & $4.8 \pm 0.2^{\mathrm{bc}}$ & $8.7 \pm 2.3^{c}$ & $61.39 \pm 5.2^{\mathrm{a}}$ & $8.12 \pm 2.8^{\mathrm{c}}$ & ND & $5.2 \times 10^{5 b}$ \\
\hline 2 & $\begin{array}{l}\text { Fresh sourish } \\
\text { smell, typical } \\
\text { fish meal }\end{array}$ & $\begin{array}{l}\text { Light } \\
\text { brown }\end{array}$ & crumbly & $5.5 \pm 0.2^{b}$ & $8.9 \pm 3.2^{\mathrm{c}}$ & $60.64 \pm 4.3^{\mathrm{a}}$ & $8.74 \pm 1.8^{b}$ & ND & $5.5 \times 10^{5 \mathrm{ab}}$ \\
\hline 4 & $\begin{array}{l}\text { Typical fish } \\
\text { meal }\end{array}$ & $\begin{array}{l}\text { Light } \\
\text { brown }\end{array}$ & $\begin{array}{l}\text { Crumbly, } \\
\text { little bit } \\
\text { compacted }\end{array}$ & $5.5 \pm 0.1^{\mathrm{b}}$ & $13.3 \pm 2.3^{b}$ & $58.14 \pm 4.8^{\mathrm{ab}}$ & $7.84 \pm 3.2^{\mathrm{c}}$ & ND & $4.8 \times 10^{5 b}$ \\
\hline $\begin{array}{l}\text { Commer- } \\
\text { cial } \\
\text { fishmeal }^{1)}\end{array}$ & $\begin{array}{l}\text { Typical fish } \\
\text { meal, } \\
\text { slightly } \\
\text { fishy and } \\
\text { smelties }\end{array}$ & $\begin{array}{l}\text { Redish } \\
\text { slightly } \\
\text { dark } \\
\text { brown }\end{array}$ & $\begin{array}{l}\text { Crumbly, } \\
\text { little bit } \\
\text { compacted }\end{array}$ & $6.7 \pm 0.1^{\mathrm{a}}$ & $16.2 \pm 2.8^{\mathrm{a}}$ & $45.86 \pm 2.8^{b}$ & $11.45 \pm 2.8^{\mathrm{a}}$ & $2.2 \times 10^{2 b}$ & $7.8 \times 10^{6 a}$ \\
\hline
\end{tabular}

Different superscript in the same collum shows the siginficantly different $(\mathrm{p}<0.05)$

ND : not determined (not identified from the sample)

${ }^{1)}$ Commercial fishmeal within 4 month storing since it was taken from poultry shop

${ }^{2)} \mathrm{pH}$ was measure by diluted fish meal with water $1: 1(\mathrm{w} / \mathrm{v})$, mixed well and stand up for 15 minutes then measured the $\mathrm{pH}$

${ }^{3)}$ Moisture content, crude protein and crude fat analysed by the method of AOAC (1997)

${ }^{4)}$ Total fungi and total bacteria determinated by the method of Fardiaz(1993)

number of proteolytic's bacteria could be maintained up to 2 months of storage. Even though shown an increasing trend in the last 2 months of storage $\left(4.8 \times 10^{5}, 5.2 \times 10^{5}, 5.5 \times 10^{5}\right.$ $\mathrm{cfu} / \mathrm{g})$, the total number of proteolytic's bacteria was still lower than that in the commercial fish meal $\left(7.8 \times 10^{6} \mathrm{cfu} / \mathrm{g}\right)$ which was stored at the same condition $(\mathrm{P}<0.05)$. It can be noted in this study, the increase of the moisture content during storage promoted the growth of the mold and proteolytic's bacteria, and the activity of proteolytic's bacteria causing changes of nutrient composition.

Loss of weight of fish meal that was calculated from fresh, after acidification and drying was lower than that was made by conventional method. Barlow and Windsor
(1984), noted that to obtain high yield and quality of fish meal, it is necessary the method skill and experience in cooking, pressing and drying. Cooking temperature, screening materials, pressing and drying are factors related to the decreasing of yielding and quality of fish meal (Marki, 1990; Babbitt et al., 1995; Opstvedt et al.,2003). In the manufacture of fish meal with acidification technique, intra-/extra-cellular fluid flows out as a result of penetration of FVWextract through osmotic pressure differences. In the conventional techniques, the liquid is discharged as a result of mechanical pressure, therefore the fluid was much more loosed. Marki (1990) and Jensen (1990) reported that increasing the pressure may lead to the weight loss because the mixture of water, oil and some solids was 
squeezed out through the perforations.

The FVW-extract has been indicated having a potential lactic acid bacteria that possibly be used as a natural control to the nutrition damage of "Ikan rucah" (Sulistiyanto and Nugroho, 2009). Lactic acid bacteria's (LABs) has been applied in feed preservations as a bio-control agents of E.coli and S. aureus (Rahayu et al., 2004). Bacteriocins that are produced LABs such as : acidophilin, acidolin, lactobacillin, and lactocidin have had demonstrated an inhibitory activity against Klebsiella $s p$, Pseudomonas $s p$, Bacillus sp, Proteus sp, Salmonella sp, Shigella s, Staphylocccus $s p$, Vibrio $s p$ and enteropathogenic E. coli (RisØen et al., 2004 ; Rehman et al., 2009). Agustina et al. (2011) and Sulistiyanto et al. (2011) noted a number and viability of LAB's of FVW-extract could be maintained in the pellet form. The number LAB's of FVW-extract remained high in the pellet, even the moisture content was $8-14 \%$. That was significantly increased the total number of the LABs and suppressed the number of Salmonella $s p$. and Coliform in both digesta of the small and large intestines of the chickens. Lactic acid bacteria helps to develop and stabilize a competent microflora in the gastrointestinal tract that should successfully avoid the proliferation of pathogens (Fuller, 1977; Khaksefidi and Ghoorchi, 2006). It could be considered in this experiment that the conditions in the storage period of 2 months allegedly as a result of group activity of LABs. LABs are groups of proteolytic facultative bacteria, the activity of LABs produces lactic acid that may play a role in inhibition of the growth decomposing microbes, so the $\mathrm{pH}$ and total number of proteolytic bacteria remain no significant changes. In term of commercial fish meal, activity of non-LABs proteolytic's bacteria presumably increased after 2 months of storage, as shown the increase in the bacteria population and the $\mathrm{pH}$ that leads to alkaline. Decomposition of proteins that lead to damage was marked from the release of ammonia thus encourage an increasing of $\mathrm{pH}$ value.

The lactic acid bacteria numbers play the important role on the preservation effect of fish product. Increasing number of LABs reduced the number of non-LABs of fermented fish. Crude protein and extract ether of fermented fish increased in line with the increasing of FVWextract (Sumarsih et al., 2010; Utama and Sumarsih (2010). Lactobacillus sp may inhibit the growth of decomposing bacteria
(Enterobactericeae and Pseudomonas spp.) of the fish fillet (Katikou et al., 2007). The accumulation of metabolic products of cell may toxic to the cells, and the cells became death, therefore it eliminated the contamination of fermented fish from Coliform and Salmonella sp. up to 2 weeks (Ndaw et al., 2008). Inhibitory mechanism of LABs to the growth and development of pathogenic and decomposing bacteria considered be the causative effect of the LAB's number and its organic acids. The organic acid of the LABs inhibited the growth and metabolism of non-LABs in particular non acidic resistant bacteria (Lindgern, 1992; Amin and Leksono, 2001; Carey et al., 2008; Christine et al., 2002). Salmonella sp., E.Coli and Clostridium sp., are the pathogenic and decomposing bacteria that are sensitive to acidic condition (Jay et al., 2005). Organic acids and its concentration affected the effectiveness of organic acid to the preservation (Woolford, 1992). Introducing organic acid and decreasing $\mathrm{pH}$ are constitutes effective method for feeds preservation. Application of organic acid to control bacteria and fungi, provide good impact on animal that consume acidified feedstuffs (Seerly, 1993 and Gerritsen et al., 2010). This research has been proven that organic acid in the extracts of FVW-extract provide acid condition during the process of soaking and the moisture content of the acidified fish meal was bellow $12 \%$, so the fungi did not grow. Thus could be argued that the LABs and FVW-extract maintaining the nutrient content such as $\mathrm{CP}$ and EE during storing is conducted by the role of lactic acid bacteria and the role of $\mathrm{pH}$ during the process of dipping and storing simultaneously. Therefore, dipping in the FVW-extract effectively maintained physical performances, $\mathrm{pH}$, moisture, crude protein, extract ether and number of proteolytic bacteria of fish meal up to 2 months of storing. Dipping in the FVW-extract provide better characteristics of physical, chemical and biological of the "rucah" fish than that of commercial fish meal.

\section{CONCLUSION}

In conclusion, the acidified "rucah" fish with FVW-extract technically effective reduced the weight loss in fish meal processing and effectively maintain characteristics of physicorganoleptycal, chemical and microbiologycal up to 2 months of storing. Dipping of "rucah" fish 
into FVW-extract provided better physicorganoleptycal, chemical and microbiologycal characteristics than that of commercial fish meal.

\section{ACKNOWLEDGMENT}

The authors wish to thank you to Agustina D.A., Kelik I.H and Happy H. for supporting activities to the laboratory analysis of the sample.

\section{REFFERENCES}

Agustina, D.A., B. Sulistiyanto and C.I.Sutrisno. 2011. Effect of level of molasses and age of incubation on the score of gram bacteria and totally number of lactic acids bacteria in the pellet made from agro-industrial by products. The 3rd IC-ISLAB "Better Life with Lactic Acid Bacteria: Exploring Novel Functions of Lactic Acid Bacteria". Gadjah Mada University, Yogyakarta, Indonesia. January $21-22^{\text {th }}, 2011$

Amin, W and T. Leksono. 2001. Analisis pertumbuhan mikroba ikan jambal siam (Pangasius sutchi) asap yang telah diawetkan secara ensiling. J. Natur Indonesia. 14(1):1-9

Amiza, M.A., N. S. Ashikin, and A.L. Faazaz. 2011. Optimization of enzymatic protein hydrolysis from silver catfish(Pangasius $s p$ ). Intl. Food Res. J. 18:751-757.

AOAC. 1997. Official Methods of Analysis. 16 ${ }^{\text {th }}$ Ed. The Association of Official Analytical Chemists -AOAC International, Gaithersburg, Md.

Babbitt, J.K.,R.W. Hardy, K. D. Reppond and T. M. Scott. 1995. Processes for improving the quality of whitefish meal. J. Aqua. Food Prod. Tech. 3(3): 59-68

Barlow, S.M and M.L.Windsor. Fishery byproducts. IAFM-International association of fish meal manufacturers. No.19. page 1-23.

Carey, C.M., M. Kostrzynska, S. Ojha and S.Thompson. 2008. The effect of probiotics and organic acids on Shiga-toxin 2 gene expression in enterohemorrhagic Escherichia coli 0157:H7. J. Microb. Methods.73(2):125132

Christine M., C. Vergẻs, E. Maguin, M.Y. Mistou, P. Anglade and J.F. Chich. 2002. Lactic acid bacteria and proteomics: Current knowledge and perspectives. J. Chromatography 771(12): $329-342$
Fardiaz, S. 1993. Analisis Mikroorganisma Pangan. Edisi Pertama. Cetakan ke-1 Raja Grafindo Persada, Jakarta.

Folador, J.F., L.K.K.Lilienthal, C.W.Parsons, L.L. Bauer, P.L. Utterback, C.S. Schasteen, P.J. Bechtel and G.C.Fahey,Jr. 2006. Fish meals, fish components, and fish protein hydrolysates as potential ingredients in pet foods. J. Anim. Sci. 84: 2752-2765. DOI:10.252/JAS.2005-560

Fuller R. 1977. The importantance of lactobacillus in maintaining microbial balance in the crop. Br. Poult. Sci. 18: 85-94

Gerritsen, R., A.J. van Dijk, K. Rethy and P. Bikker. 2010. The Effect of blends of organic acids on apparent fecal digestibility in piglets. Livestock Sci. 134:246-248

Jay, J.M., M.J.Loessner and D.A.Golden. 2005. Modern Food Microbiology. $7^{\text {th }}$ Ed. Spinger Science and Bussiness Media Inc. New York.

Jensen N.C. 1990. Quality fish meal:specification and use in aquaculture and fur farming. Proc. Intl. By-Product Conference. Anchorage-Alaska, April 1990. Page 27-130

Katikou, P., I. Ambrosiadis, D. Georgantelis, P. Koidis and S. A. Georgakis. 2007. Effect of Lactobacillus cultures on microbiological, chemichal and odour changes during storage of rainbow trout fillet. J. Sci. Food and Agric. 87 (3): 477-484

Khaksefidi, A and T.Ghoorchi. 2006. Effect of probiotic on performance an immune competence in broiler chicks. J. Poult. Sci. 43: $296-300$

Lindgern, S. 1992. Storage of waste products for animal feed. In: Brian J.B.Wood(Ed). The Lactic Acid bacteria I. The Lactic Acid Bacteria in Health and Deseases. Department of Bioscience and Biotechnology. Univ. of Strathclyde. Glasgow. UK. Page 50-58

Malaka, R and A. Laga. 2005. Isolasi dan identifikasi Lactobacillus Bulgaricus strain Ropy dari yogurt komersial. J. Sains dan Teknologi. 5(1):50-58

Marki B. 1990. Effects of process parameters and raw materials freshness on fish meal quality. Proc. Intl. By-Product Conference. Anchorage-Alaska, April 1990. Page 105107

Ndaw, A. A. Zinedine., M. Faid and A. Bouseta. 2008. Effect of controlled lactic acid bacterial fermentation on the microbiological and chemical qualities of Moroccan Sardines (Sardina pilchardus). J. Act. Microb. Immun. 
Hungarica. 55 (33):295-310.

Opstvedt J., E. Nygård E., T.A Samuelsen,G. Venturini G., U. Luzzana and H. Mundheim . 2003. Processing effects on protein quality of extruded fish feed. J. Sci. of Food and Agric 83(8): 775-782

Prachyakij, P., J. Schnurer, W. Charernjiratrakul and D. Kantachote. 2006. Selection and identification of lactic acid bacteria that inhibit yeast contaminants isolated from fermented plant beverages. Songklanakarin. J. Sci. Tech. 29(2):211-218

Rahayu, E. S., E. Harmayani, T. Utami and K. Handini. 2004. Pediococcus acidilactici F-11 penghasil bakteriosin sebagai agensia biokontrol E. Coli dan S. aureus pada Sayuran Segar Simpan Dingin. J. Agritech 24 (3):113-124

Rehman, H., W. Vahjen, A.K. Parsini. A.Ijaz and J. Zentek. 2009. Influence of fermentable cahbohydrate on the intestinal bacteria and enteropathogens in broiler. World Poult. Sci.J. 65(1):75-90

Risøen, P.A., Røning, P., Hegna, L.K. and Kolstø, A.B. 2004. Characterization o a broad range antimicrobial substance from bacillus cereus. J. Appl. Microb. 96: 648-655

SAS Institute. 1982. SAS User Guide: Statistics, pp: 139-200 (SAS, Raleigh, SAS Institute).

Seerly, R.W. 1993. The important acidification in monogastric nutrition. In: Biotechnology the use of sciencetifically proven natural products to increase practical value. APLTAltech. Page 123-132

Solar M.C.L., N.X. Zeng, T.K. Essert, T.D. Truong, C. Pina, J.S.Cullor, W.L.Smith and R.Larrain. 2005. Disinfection of fishmeal with radiofrequency heating for improved quality and energy efficiency. J. Sci. Food and Agric. 85:2273-2280

Sulistiyanto, B. and K. Nugroho. 2009. Physically and microbiologycally performance of acidified fish meal that are made by dipping into extract solution of sauerkraut. J. Indonesian. Trop. Anim. Agric. 34(4):248252

Sulistiyanto, B., S. Sumarsih, C.S. Utama and C.I. Sutrisno. 2011. Effect of dietary pellet containing of lactic acid bacteria to the microbial performance of the intestine of broiler chicks. The 3rd IC-ISLAB "Better Life with Lactic Acid Bacteria: Exploring Novel Functions of Lactic Acid Bacteria". Gadjah Mada University, Yogyakarta, Indonesia. January $21-22^{\text {th }}, 2011$

Sumarsih S., B. Sulistiyanto, H.S. Adi and C.S. Utama. 2010. Pengaruh aras starter Lactobacillus sp. Terhadap performa mikrobiologi silase ikan dilihat dari total bakteri, bakteri asam laktat dan fungi. J. Kesehatan 3(1):43-50

Utama C.S. and A. Mulyanto. 2009. Potensi limbah pasar sayur menjadi starter fermentasi. J. Kesehatan 2(1):6-13

Utama C.S. and S. Sumarsih. 2010. Pengaruh penambahan aras ekstrak kubis sortir dan lama pemeraman terhadap kandungan nutrisi silase ikan. J. Kesehatan 3(1):27-32

Woolford, M.K. 1992. Feed preservation methods. In: Improving Nutrient Utilization While Reducing Pollution: A New demension through biotechnology. APLTAltech. Page 173-188 